\title{
Public and Private International Law Bulletin
}

\section{Compensation for Unlawful Practices related to Administrative Detention of Foreigners in Turkey ${ }^{*}$}

\section{Gamze Ovacık* (i)}

\begin{abstract}
This paper analyzes the evolution of the case law in Turkey concerning compensation of unlawful practices of administrative detention. Such cases happen when implementation of administrative detention is unlawful in terms of right to personal liberty and security, or when the administrative detention conditions are against human dignity. The paper follows an empirical and analytical method as the analysis is built on the decisions of the Turkish Constitutional Court ("CC") in individual applications and on the judgments by local courts. Accordingly, as explained in the first section, in the first phase of CC's decisions, the lack of a special compensation mechanism for unlawful practices of administrative detention was recognized and compensation was granted in favor of the applicants. Second section of the paper analyzes the landmark decision of CC where it changed its case law and required exhaustion of administrative full remedy action for compensation claims related to administrative detention. Building on this background, in the last two sections of the paper first, it is assessed whether administrative full remedy action is an effective legal remedy with respect to compensating unlawful administrative detention practices and second, a critical analysis is offered on CC's approach to the claims of compensation in the light of its landmark decision.
\end{abstract}

\section{Keywords}

Administrative Detention, Immigration Detention, Detention Conditions, Unlawful Detention, Compensation for Detention

\footnotetext{
* This article is based on the author's doctoral thesis.
}

** Correspondence to: Gamze Ovacık (PhD Researcher), Bilkent University, Faculty of Law, Department of Public International Law, Ankara, Turkey. E-mail: gamze.ovacik@bilkent.edu.tr ORCID: 0000-0002-3665-1097

To cite this article: Ovacik G, "Compensation for Unlawful Practices related to Administrative Detention of Foreigners in Turkey" (2021) 41(1) PPIL 41. https://doi.org/10.26650/ppil.2021.41.1.803246 


\section{Compensation for Unlawful Practices related to Administrative Detention of Foreigners in Turkey}

\section{Introduction and Methodology}

This paper aims to showcase how the case law in Turkey evolved around compensation for unlawful practices related to administrative detention of foreigners. Such cases arise either when implementation of administrative detention is unlawful in terms of right to personal liberty and security, or when the conditions of administrative detention are against human dignity. In this context, by using an empirical and analytical methodology, this paper will analyze the case law of the Turkish Constitutional Court ("CC") as well as the newly emerging local court decisions.

Due to the lack of a central database of decisions of Turkish local courts, it was a challenge to collect court decisions and information on case law within the scope of this paper. I obtained the local court decisions analyzed in this article and information on judicial practices from lawyers from the field, Bar Associations and non-governmental organizations working on refugee law. $\mathrm{CC}$ decisions on the other hand were available at the Court's website. I spent the utmost effort to ensure sufficient diversity and plentitude of the analyzed court decisions and I am confident that the body of case law reviewed, consisting of 101 judgments from the $\mathrm{CC}$ and different local courts, constitutes a representative sample of Turkish court decisions on compensation for unlawful detention practices.

In Turkish legal framework, the right to compensation for unlawful deprivation of liberty is not expressly provided in rules regarding administrative detention of foreigners, however, it is provided in Article 19(9) of the Constitution, in line with Article 5(5) of ECHR. Both provisions express that, damages suffered due to treatment contrary to those articles on the right to personal liberty and security, shall be compensated by the state. This regulation shows how much weight is given to the right of personal liberty and security as in the case of ECHR, there are no other provisions that require party states to secure a right to compensation in their domestic system for violation of one of the Convention rights, apart from compensation for wrongful conviction provided in Article 3 of Protocol 7 to the ECHR. ${ }^{1}$

Whereas the type of compensation addressed above is related to the lawfulness of detention, the other type of compensation arising from administrative detention practices relates to the conditions of detention. In order to trigger the right to compensation, severity of administrative detention conditions should reach at least the level of incompatibility with human dignity as expressed in Article 17 of the Constitution, which corresponds to degrading treatment in Article 3 of the ECHR.

1 Nuala Mole and Catherine Meredith, Asylum and the European Convention on Human Rights (Council of Europe Publishing 2010) 167. 
Although there is no separate provision providing for a compensation right for violations of this nature, right to effective remedy as reflected in Article 40 of the Constitution and Article 13 of the ECHR requires presence of a legal remedy in the domestic legal system, capable of awarding compensation for the rights violations arising from such treatment.

Based on this framework, below is an analysis of how Turkish judiciary provides for compensation for cases of unlawful administrative detention and cases of complaint against conditions of administrative detention.

\section{Case Law of CC regarding Compensation for Unlawful Administrative Detention Practices}

In Turkish context, compensation demands concerning unlawful administrative detention practices have been dominantly put forward through individual application to $\mathrm{CC}$, which is a procedure designed for claims of violations of Constitutional rights intersecting with rights secured by ECHR. Accordingly, CC evaluated demands for compensation concerning lawfulness and conditions of administrative detention practices, which were conducted before ${ }^{2}$ and after $^{3}$ the enforcement of the Law on Foreigners and International Protection ("LFIP") which is the first and the main legislation regulating administrative detention in Turkey. It should be noted that

2 2013-655 [2016] Constitutional Court F.A. and M.A.; 2013-1649 [2016] Constitutional Court A.V. and Others; 2013-8735 [2016] Constitutional Court F.K. and Others; 2013-8810 [2016] Constitutional Court T.T.; 2014-2841 [2016] Constitutional Court A.S.; 2014-688 [2017] Constitutional Court I.U.; 2014-1368 [2017] Constitutional Court A.S.; 2014-2114 [2017] Constitutional Court U.U.; 2014-1369 [2017] Constitutional Court A.B.; 2014-3955 [2018] Constitutional Court R.A.; 2014-2427 [2018] Constitutional Court D.D.; 2013-9673 [2015] Constitutional Court Rida Boudraa; 2014-19690 [2018] Constitutional Court M.S.S.

3 2014-13044 [2015] Constitutional Court K.A.; 2014-15876 [2016] Constitutional Court I.I.; 2014-15824 [2016] Constitutional Court I.S. and Others; 2014-15769 [2017] Constitutional Court B.T.; 2014-16413 [2017] Constitutional Court I.M. and Z.M.; 2014-18827 [2017] Constitutional Court A.A.; 2015-15764 [2018] Constitutional Court F.A.A.; 201416575 [2018] Constitutional Court K.K.; 2015-6543 [2018] Constitutional Court G.G.; 2015-7305 [2018] Constitutional Court M.A.; 2015-1474 [2018] Constitutional Court Manzura Jumaeva; 2015-9776 [2018] Constitutional Court F.M.; 2015-8465 [2018] Constitutional Court K.M.; 2014-6493 [2018] Constitutional Court M.B. and M.Z.; 2014-16577 [2018] Constitutional Court K.A. and N.A.; 2014-19436 [2018] Constitutional Court M.A.; 2017-31040 [2019] Constitutional Court Z.K.; 2014-17572 [2019] Constitutional Court A.A. and Others; 2015-5371 [2017] Constitutional Court Gulalek Begnyazova; 2017-6077 [2017] Constitutional Court F.R.; 2017-10453 [2017] Constitutional Court Y. H.; 2016-5688 [2017] Constitutional Court A. S.; 2015-516 [2019] Constitutional Court Daygınat Magomedzhamilova and Others; 2016-23744 [2020] Constitutional Court Nuli Aihetamu; 2017-23177 [2018] Constitutional Court P.A.; 2017-38222 [2018] Constitutional Court F.Y.; 2015-9409 [2019] Constitutional Court Abdullah Omar; 2016-26503 [2017] Constitutional Court Fatma Bakki; 2017-5839 [2017] Constitutional Court M. I.; 2017-19685 [2017] Constitutional Court Zamow Muhammed; 2015 -11553 [2019] Constitutional Court M. Q.; 2016-27304 [2017] Constitutional Court H. B.; 2015-4459 [2018] Constitutional Court Yulia Matur (Anikeeva); 2015-10717 [2019] Constitutional Court Fadi Mansour; 2014-19481 [2018] Constitutional Court G.B. and Others; 2015-33 [2019] Constitutional Court Sara Rahmazani and Others; 2015-6724 [1.8.20220] Constitutional Court Solmaz Mamedova; 2019-14737 [2019] Constitutional Court T. S.; 2015-9727 [2019] Constitutional Court Feruza Masulmankulova; 2015-9777 [2019] Constitutional Court A.O.C and Others; 2015-10697 [2019] Constitutional Court Mohammaod Alhowees; 2015-10715 [2019] Constitutional Court Nader Alomar; 2015-17761 [2019] Constitutional Court A.A.K.; 2015-18312 [2019] Constitutional Court A.E.H. ve S.E.I.; 2015-19133 [2019] Constitutional Court R.M. and Others; 2016-1508 [2020] Constitutional Court Mohamed Khaled Alswadane; 2016-4754 [2020] Constitutional Court Kristina Lutstsato and Others; 2016-12585 [2020] Constitutional Court Sonia Nasir; 2016-12809 [2020] Constitutional Court Kemal Salpagarov; 2016-35009 [2019] Constitutional Court Abdulkadir Yapuquan; 2016-40091 [2020] Constitutional Court Mohamed Sabry Aly Azzazy and Others; 2016-70639 [2019] Constitutional Court Magomed Emin Osmaev; 2017-20451 [2020] Constitutional Court Ali Javid and Others; 2017-24530 [2020] Constitutional Court Mostafa Soleymani Olyae and Others; 2019-7023 [2019] Constitutional Court A.H.; 2019-9386 [2019] Constitutional Court Nashaat Alalloush; 2019-18314 [2019] Constitutional Court Basel Khalil; 2019-19576 [2020] Constitutional Court Behzad Zareei. 
before the enactment of LFIP there were no legal remedies available in Turkish law for challenging the lawfulness of administrative detention let alone for obtaining compensation for unlawful administrative detention practices.

The landmark decision of $\mathrm{CC}$ on the issue of compensation for unlawful administrative detention practices is its decision dated 30 November 2017, rendered upon the individual application No. 2014/157694. Before this decision, CC rendered six decisions on merits ${ }^{5}$ upon claims concerning both lawfulness and conditions of administrative detention measures carried out and finalized before the entry into force of LFIP. Whereas, again before the landmark decision, CC issued ten decisions ${ }^{6}$ on administrative detention practices where the applicants were either being held under administrative detention when LFIP entered into force or they were taken under administrative detention after its entry into force. One of these applications contained claims only with respect to conditions of administrative detention, ${ }^{7}$ and six of them concerned only lawfulness of administrative detention, ${ }^{8}$ whereas three applications ${ }^{9}$ covered claims concerning both lawfulness and conditions of administrative detention. So, it was possible for this second category of applicants to lodge a complaint against lawfulness of administrative detention as per the legal remedy provided by LFIP.

In the first category of decisions before LFIP's entry into force, when assessing lawfulness of detention, CC referred to Article 5 of the ECHR and Article 19(2) and (8) of Constitution which respectively foresee grounds for deprivation of liberty exhaustively, and, a right to judicial complaint against detention that should be capable of resulting in release of the applicant if detention is found unlawful. ${ }^{10}$ Based on this, due to the lack of clear regulation in the law as to conditions, period, extension, notification and legal remedies with respect to administrative detention as well as access to lawyer and interpreter by the detainee, the administrative detention measures were found unlawful. ${ }^{11}$

10 It should be noted that in the context of unlawful detention, Article 19(8) comes into play as lex specialis with respect to right to effective remedy, which is otherwise guaranteed by Article 40 of Constitution as lex generalis, concerning any claims of violation of fundamental rights and liberties set forth in Constitution. The same relation exists between Article 5(4) and Article 13 within the frame of ECHR as emphasized by ECtHR. Please see: Amie and Others v Bulgaria [2015] ECtHR 58149/08 [63]; Yarashonen v Turkey [2014] ECtHR 72710/11 [34]; Chahal v the United Kingdom [1996] ECtHR 22414/93 [126]; 2014-15769 (n 4) para 69.

11 2013-655 (n 3) paras 126-138, 150-161; 2013-1649 (n 3) paras 118-129, 143-153; 2013-8735 (n 3) paras 111-122, 135-145; 2013-8810 (n 3) paras 104-115, 128-138; 2014-2841 (n 3) paras 100-109, 122-129; 2013-9673 (n 3) paras 62-79.
} 
In all of these decisions except for one, ${ }^{12}$ the Court proceeded with the claim that the right to compensation provided in Article 5(5) of the ECHR and Article 19(9) of Constitution was violated. CC stated that it is compulsory to establish a mechanism that enables demanding compensation for administrative detention practices violating Article 19 and arriving at the conclusion that the Turkish legal system lacks such a mechanism, compelled CC to rule that Article 19(9) has been violated. ${ }^{13}$ These decisions of $\mathrm{CC}$, which assess the legal situation in Turkey before the enactment of LFIP, are essentially in line with many violation decisions of the ECtHR against Turkey. The landmark decision of the ECtHR was Abdolkhani and Karimnia v. Turkey ${ }^{14}$ and many others ${ }^{15}$ then followed the principles and determinations made in this decision.

As to the individual applications where $\mathrm{CC}$ assessed lawfulness of administrative detention practices subject to LFIP, the first decision ${ }^{16}$ represents the position of CC that remained unchanged until the landmark decision No. 2014/15769. Accordingly, as opposed to its earlier decisions, $\mathrm{CC}$ recognized that there are appropriate mechanisms in place within the legal framework to ensure that administrative detention practices fulfill the conditions of lawfulness and non-arbitrariness. However, procedures need to be conducted with due diligence and because of the procedural flaws determined in implementation of administrative detention based on concrete circumstances of the case, it was concluded that Article 19 was violated. ${ }^{17}$ Because of this conclusion, CC granted compensation in favor of the applicant.

In another subsequent case, ${ }^{18} \mathrm{CC}$ followed the suite of its decision explained above and ruled for compensation in favor of the applicant as it again found violations with respect to Article 19 of Constitution. ${ }^{19}$ As per the claims of applicants, CC also assessed compliance with Article 19(9) of Constitution on compensation for unlawful deprivation of liberty. In this respect, $\mathrm{CC}$ did not depart from its case law relating to administrative detention practices carried out before LFIP's entry into force and

12 2013-655 (n 3) paras 138-150; 2013-1649 (n 3) paras 130-142; 2013-8735 (n 3) paras 123-134; 2013-8810 (n 3) paras 116-127; 2014-2841 (n 3) paras 110-121. It should be noted it is also assessed in these cases whether the applicants have been duly and immediately notified as to administrative detention and it was concluded that Article 19 (4) of Constitution which brings a condition of notification was violated.

13 2013-655 (n 3) paras 162-170; 2013-1649 (n 3) paras 154-162; 2013-8735 (n 3) paras 146-154; 2013-8810 (n 3) paras 139-147; 2014-2841 (n 3) paras 131-137.

14 Abdolkhani and Karimnia v Turkey [2009] ECtHR 30471/08.

15 To cite several of them; Yarashonen v. Turkey (n 11); Musaev v Turkey [2014] ECtHR 72754/11; Moghaddas v Turkey [2011] ECtHR 46134/08; Athary v Turkey [2012] ECtHR 50372/09; Tehrani and Others v Turkey [2010] ECtHR 32940/08, 41626/08 and 43616/08; Dbouba v Turkey [2010] ECtHR 15916/09; Alimov v Turkey [2016] ECtHR 14344/13.

19 Apart from the two cases, in other decisions that relate to lawfulness of administrative detention and that were rendered before the decision in the individual application No. 2014/15769, CC found applications 2014-15876 (n 4); 2015-5371 (n 4) inadmissible due to application after the expiry of the deadline for individual application, and struck the individual applications 2016-27304 (n 4); 2016-26503 (n 4); 2017-5839 (n 4); 2017-19685 (n 4); 2017-10453 (n 4) out from the list due to withdrawal of individual application. 
stated that the constitutional provision is violated since, there is no special mechanism in domestic law for compensation of damages arising from unlawful deprivation of liberty. ${ }^{20}$

As to the applicants' claims concerning administrative detention conditions, CC does not make any distinction in its legal assessment based on whether administrative detention was carried out before the entry into force of LFIP or not. Presumably, the reason for that is that LFIP does not bring any legal remedy as to administrative detention conditions. In one case ${ }^{21}$ where the applicant was held in Yalova police headquarters, it was found that such claims are inadmissible due to being manifestly illfounded for having not attained the minimum level of severity to fall within the scope of Article $17 .^{22}$ Whereas, in other seven individual applications, the applicants of which were all held in Kumkap1 Removal Centre in İstanbul, ${ }^{23}$ upon detailed assessment, the Court determined that the conditions were incompatible with human dignity and thus violated Article 17 of Constitution. In these seven cases, it was also evaluated whether an effective remedy within the meaning of Article 40 of Constitution was provided in Turkish law to the applicants in connection with their claims of violation of Article 17. In finding violation, the Court followed ECtHR's case law, as to what constitutes effective remedy with respect to detention conditions. Accordingly, CC stressed that preventive remedies which aims towards improvement in the material conditions of detention and compensatory remedies providing compensation for damages caused by these conditions must complement each other. ${ }^{24}$ Upon assessing Turkish law before and after LFIP, the Court concluded by ruling on violation of Article 17 of Constitution with respect to detention conditions and violation of Article 40 of Constitution with respect to the right to effective remedy in connection with detention conditions in the seven decisions mentioned in the above paragraph, in addition to violation of Article 19 of Constitution with respect to lawfulness of administrative detention and consequently on payment of compensation to the applicants in all of the individual applications.

\section{Change in CC's Established Case Law on Compensation for Unlawful Administrative Detention Practices}

After issuing these eight decisions granting compensation, with its decision No. 2014/15769, CC radically changed its position. CC started to respond positively to the questions of whether Turkish legal system provides an effective legal remedy that allows individuals, compensation for unlawful administrative detention practices.

$20 \quad 2014-15824$ (n 4) paras 173-178.

$21 \quad 2013-9673$ (n 3) para 64.

22 Please see Boudraa v Turkey [2017] ECtHR 1009/16 [31-36] for conclusions of the ECtHR on the contrary.

23 Some of the applicants in 2014-13044 (n 4) also complained about the conditions in Adana Reception and Accommodation Centre, Adana and Yalova Removal Centres and several police headquarters that they were held in.

24 2013-8735 (n 3) paras 40-58; 2013-655 (n 3) paras 50-68; 2013-1649 (n 3) paras 44-62; 2014-2841 (n 3) paras 35-50; 2013-8810 (n 3) paras 35-53; 2014-15824 (n 4) paras 90-96; 2014-13044 (n 4) paras 66-82. 
According to the line of reasoning that this decision follows, while the administrative courts do not have any authority in reviewing lawfulness of administrative detention, they do have authority to rule on compensation to be paid to the individual in the case that administrative detention is found unlawful by criminal judges of peace who are competent to review the lawfulness of detention. CC refers to Article 2 of the Administrative Procedure Act No. 2577, which provides that administrative full remedy action may be issued by the persons whose personal rights are damaged directly because of administrative acts and actions. ${ }^{25}$

CC develops its argumentation first when assessing the claim of violation of the prohibition of treatment incompatible with human dignity provided in Article 17 of Constitution. CC emphasized that suspicion as to practical success of a legal remedy which has a reasonable capacity of success in theory, does not justify nonexhaustion of such remedy. ${ }^{26}$ If there are available remedies in theory, the fact that they have not been used in practice so far out of lack of information does not justify a conclusion as to ineffectiveness. Rather the existence of negative court decisions denying such compensation right, would be required for arriving at such a conclusion. ${ }^{27}$ In proclaiming availability of a legal remedy in theory, $\mathrm{CC}$ asserts that administrative detention practices rely on administrative procedures and therefore fall within the scope of administrative full remedy action which covers both acts and actions of the administration. Reference is also made to Article 125 of Constitution stating that recourse to judicial review shall be available against all actions and acts of administration. Consequently, $\mathrm{CC}$ found that the claim of violation of Article 17 of Constitution due to administrative detention conditions was inadmissible due to nonexhaustion of legal remedies.

CC builds a similar line of reasoning with respect to compensation concerning unlawfulness of administrative detention. Administrative courts are accepted to be able to provide compensation for unlawful administrative detention, through administrative full remedy action, in certain cases. CC clarifies that if the criminal judge of peace reviewing the lawfulness of detention rejects the complaint and decides that administrative detention is lawful, then administrative full remedy action, based on the argument that administrative detention is unlawful, ceases to be effective because administrative courts are not competent to review lawfulness of detention. CC confirms that for such compensation demands, it is possible to directly make an individual application to $\mathrm{CC}$ within the designated period after the finalization of the decision of criminal judge of peace. ${ }^{28}$ On the other hand, if the criminal judge of peace declares the administrative detention to be unlawful, then it is possible to initiate an administrative

$25 \quad 2014-15769$ (n 4) paras 70-71.

26 ibid 46.

27 ibid 51-52.

28 ibid 72. 
full remedy action before the competent administrative court. Contrary to its previous practice, $\mathrm{CC}$ expresses that individual application may not be lodged before exhausting administrative full remedy action. ${ }^{29}$

After the decision No. 2014/15769, CC issued forty-three ${ }^{30}$ decisions on lawfulness of detention practices, six of them within one month and ten more of them within one year after this landmark decision, almost all $^{31}$ of which resulted with inadmissibility decisions. Considering that the total number of decisions issued before the decision No. 2014/15769 is sixteen, it appears that CC parked the individual applications concerning administrative detention until determining its new position. Finally, one of the most recent decisions of $\mathrm{CC}$ that were examined, ${ }^{32}$ combines forty-three individual applications regarding lawfulness of administrative detention and similarly concludes that applications are inadmissible since not all legal remedies have been exhausted.

CC's change of position raises several issues with respect to compensation of unlawful administrative detention practices in compliance with the standards of ECHR and Constitution. Firstly, it was the shared view of the ECtHR that there is no effective mechanism in Turkish legal system for such compensation claims. It is significant that ECtHR maintained this position even after CC started to accept administrative full remedy action as an available legal remedy. In two of its latest three decisions, dated June $2018^{33}$, concerning lawfulness and conditions of detention, the ECtHR repeated its finding that Turkish legal system did not provide individuals with a remedy for unlawful administrative detention practices and referred to its previous decisions on this subject. Whereas in its latest decision about Turkey the ECtHR developed a somewhat softer approach and expressed that the legal remedies concerning administrative detention were not conducted in an effective and speedy manner, resulting in the review mechanism being wholly ineffective for the present case. The Court however noted that this conclusion should not be taken for the general effectiveness of the judicial review mechanism. ${ }^{34}$ In view of its reluctance to change its case law, it remains to be seen how the ECtHR will assess the applications that might possibly be made upon inadmissibility decisions of CC. In its decision on the case

29 ibid 73

$30 \quad 2017-38222$ (n 4); 2015-9409 (n 4); 2014-688 (n 3); 2014-1368 (n 3); 2014-2114 (n 3); 2014-1369 (n 3); 2014-16413 (n 4); 2014-18827 (n 4); 2014-3955 (n 3); 2015-15764 (n 4); 2014-2427 (n 3); 2014-16575 (n 4); 2015-6543 (n 4); 2015-7305 (n 4); 2015-9776 (n 4); 2015-8465 (n 4); 2014-6493 (n 4); 2014-16577 (n 4); 2014-19436 (n 4); 2017-31040 (n 4); 2014 17572 (n 4); $2015-516$ (n 4); 2015-1474 (n 4); 2015-4459 (n 4); 2016-23744 (n 4); 2014-19690 (n 3); 2014-19481 (n 4); 2015-33 (n 4); 2015-6724 (n 4); 2015-9727 (n 4); 2015-9777 (n 4); 2015-10697 (n 4); 2015-10715 (n 4); 2015-11553 (n 4); 2015-17761 (n 4); 2015-18312 (n 4); 2015-19133 (n 4); 2016-1508 (n 4); 2016-4754 (n 4); 2016-12585 (n 4); 2016-12809 (n 4); 2016-40091 (n 4); 2016-70639 (n 4).

31 Except for 2017-38222 (n 4); 2015-10717 (n 4); 2017-24530 (n 4); 2019-7023 (n 4); 2019-9386 (n 4); 2019-18314 (n 4); 2019-19576 (n 4); and 2019-14737 (n 4) which were struck out from the list due to withdrawal of individual application; 2017-20451 (n 4) where CC rejected the application due to failure of the applicants to submit necessary information; and 2016-35009 ( $\mathrm{n} 4)$ which is explained in detail below.

$32 \quad 2015-516$ (n 4).

33 Amerkhanov v Turkey [2018] ECtHR 16026/12 [73]; Batyrkhairov v Turkey [2018] ECtHR 69929/12 [68]. 
Yarashonen v. Turkey, the Court already refused the Turkish government's argument that administrative full remedy action was available to the applicant for demanding compensation for detrimental conditions of administrative detention and thus rejected it as an effective remedy ${ }^{35}$ Moreover, the Court clearly stated that "it is incumbent on the government to illustrate the practical effectiveness of the remedies they suggest in the particular circumstances in issue with examples from the case-law of the relevant domestic courts". After stating that the government failed to submit a single judicial decision in this regard, the Court moved on to finding a violation of Article 13 of the ECHR. ${ }^{36}$ Thus, whereas ECtHR requires presence of positive decisions to accept a legal remedy as effective, $\mathrm{CC}$, sets a lower standard by finding absence of negative decisions as sufficient. Strikingly, $\mathrm{CC}$ also referred to this decision when assessing violation of Article 40 of Constitution in its decisions before changing its case law. ${ }^{37}$

\section{Administrative Full Remedy Action as A Legal Remedy for Compensation for Unlawful Administrative Detention Practices}

It is difficult to assess whether administrative full remedy action is in practice an effective remedy due to scarcity of sample cases. As also underlined by $\mathrm{CC}$, administrative full remedy action is not commonly used concerning administrative detention practices. Nevertheless, the rare cases that were available all conclude with the rejection of compensation demands of applicants which raises doubts as to the effectiveness of this legal remedy.

One of the cases concern an Iraqi applicant about whom removal order and administrative detention decision was issued based on breach of entry rules and threat to public order. Although his first complaint against administrative detention was rejected, his final complaint was accepted by Kirklareli Criminal Judge of Peace with its decision dated 18 April 2018 because the period of administrative detention exceeded the legal limit of six months and the applicant was released approximately 1,5 months after the expiry of the six months limit. In the meantime the removal order about the applicant was also cancelled by the same court which would later assess the compensation claim.

İstanbul $1^{\text {st }}$ Administrative Court rejected the claim of compensation by stating that, the fact that the removal order was later cancelled by the court decision does not prove that administrative detention was unjust and unlawful. The Court considered that administration is under the obligation to implement the law, which foresees administrative detention in the face of existing grounds of illegal entry and threat to

35 Yarashonen $v$. Turkey (n 11) paras 59-62.

36 ibid 62-63.

$37 \quad 2014-13044$ (n 4) para 80. 
public order. ${ }^{38}$ The reasoning of the Turkish court is problematic due to several reasons. Firstly, as per the construction of LFIP, there is an unbreakable link between removal order and administrative detention decision. Article 57(2) of LFIP explicitly states that administrative detention decision may be issued about persons for whom a removal order has been issued. Therefore, administrative detention decision is always based on the existence of a removal order, it cannot be imposed independently. It is also recognized by $\mathrm{CC}$ that removal order is prerequisite of administrative detention. ${ }^{39}$ As a general rule of administrative law, if an administrative act is the basis of another administrative act, the validity of the latter affects the validity of the former. If the underlying administrative act is invalid, than other administrative acts issued on its basis is also invalid from the beginning. ${ }^{40}$ In the specific case, removal order was cancelled by the court because it was determined that the applicant in fact did not enter Turkey illegally and he cannot be deemed to pose a threat to public order under the circumstances of the case. ${ }^{41}$ So, the court thought the removal order should not have been issued by the administration in the first place, which also means that the administrative detention decision should not have been issued either. There is no doubt that, as a general rule, cancellation of an administrative act creates its legal effect retroactively, the result being as if the cancelled act has not been established at all. ${ }^{42}$ Therefore, in arguing that cancellation of removal decision does not necessarily render administrative detention unlawful from the beginning, the court is contradicting with its own reasoning.

Moreover, the administration relied on the same grounds for issuance of both removal order and administrative detention decision. So, by cancelling the removal order, while the applicant was still under detention, the administrative court also declared its opinion on the reasons of administrative detention. Therefore, although the administrative court is not competent to rule on the lawfulness of administrative detention decision, it does not make sense to accept that the same administrative authority was obliged to establish the administrative detention decision, whereas it was unjustified to issue the removal order, both based on the very same reasons. The court did not take into account these principles of administrative law in rejecting the full remedy action.

Furthermore, let alone the discussion on the cancellation of the removal order, it is not possible to concur with the court's rejection of compensation claim in the

38 E 2018/1254 K 2018/2324 (İstanbul 1 Administrative Court).

$39 \quad 2016-35009$ (n 4$)$ para 118.

40 E1975/542 K1975/519 (Council of State 3 Chamber); E1991/112 K1991/154 (Council of State 5 Chamber); E1980/32 K1980/39 (Council of State 3 Chamber); E2003/14 K2003/25 (Council of State 1 Chamber).

41 E 2017/1322 K 2018/338 (İstanbul 1 Administrative Court).

42 Halil Kalabalık, İdare Hukuku Dersleri Cilt-II (4th edn, Seçkin Yayıncılık 2019) 102; Ramazan Çağlayan, İdare Hukuku Dersleri (6th edn, Adalet Yayınevi 2018) 393; E1937/202 K1938/14 (Council of State 2 General Council of Lawsuit Chambers); E1965/21 K1966/7 (Council of State Board for Unification of Case Law) 21; E1993/247 K1994/559 (Council of State 3 General Chamber of Administrative Lawsuits). 
face of presence of a decision by the criminal judge of peace finding administrative detention unlawful. This decision determines that, in any case, administrative detention became unlawful after the expiry of six months limit for administrative detention. Therefore, in any case, the applicant should be entitled to compensation for the period of administrative detention after this period until when he was finally released. Court's conclusion of rejecting compensation claims contradicts with the general rule that the administration is liable to compensate the damages resulting from its acts and actions as provided in Article 125 of Constitution and the special rule providing that damage suffered by persons for treatment contrary to personal liberty and security is to be compensated by the state as provided in Article 19 of Constitution.

In another case the administrative court rejected the full remedy action based on expiration of application deadline ${ }^{43}$ and the regional administrative court concurred ${ }^{44}$ The applicant in this case was released from detention on 22 November 2017 and the administrative full remedy action was initiated on 23 March 2008, approximately two months later than sixty days administrative lawsuit deadline which normally starts running with the release of the applicant from detention. Considering that CC's decision No. 2014/15769 became public by being published in the Official Gazette dated 6 February 2018, the change of case law of CC accepting administrative full remedy action as an effective remedy became known to the applicant only after the expiry of the period of administrative lawsuit deadline, which possibly explains the late application to the administrative court. In consideration of the procedural guidance of $\mathrm{CC}$ to administrative courts in its landmark decision, the administrative courts are expected to initiate the judicial deadline from the date of publication of CC's decision No. 2014/15769 for the sake of providing access to the full remedy action. If this court have done so, the full remedy action could be deemed to be within the judicial deadline and the court could review the merits of the case.

One other case relates to different occurrences of deprivation of liberty through administrative detention and imposition of reporting obligation. The case was initiated against administration's rejection of the request by the applicant for the transfer of her daily reporting obligation duty in Kırıkkale to İstanbul. The applicant also requested moral compensation claiming that the measure amounted to administrative detention in Kırıkkale due to having to be away from her spouse and children in İstanbul. The court does not object to the characterization of the measure as administrative detention. The court rejects the compensation request by stating that there is no obstacle before imposing administrative detention and reporting obligations to foreigners, who pose threat to public order, and therefore there is no causality between the damage and 
administrative act. ${ }^{45}$ If the court concurs with the qualification of the measure as administrative detention, it would be expected to rule that jurisdiction to decide on lawfulness of administrative measure belongs to criminal courts of peace rather than affirming the lawfulness of the measure. If on the other hand, it decides on the claim of unlawfulness and compensation right arising from it, it would be expected to reject such qualification, for the sake of legal consistency. The decision was then approved by the regional district court on appeal. ${ }^{46}$

In a case with similar facts the applicant requested the cancellation of "unknown location" ("semt-i meçhul") code imposed by the administration based on noncompliance with reporting obligation in Kirklareli whereas he resides in İstanbul. He also demanded compensation for having been taken under administrative detention because of imposition of that code. As different from the previous case, the court here explicitly spelled out the unlawfulness of the act that caused the implementation of administrative detention and cancelled the administrative act of imposition of the code. However, it rejected the compensation request based on the same reasoning of lack of causality. ${ }^{47}$

Administrative full remedy action was tried to be used before the entry into force of LFIP as well. In two cases where the applicants were taken under administrative detention for removal due to rejection of their international protection ("IP") application and appealed the rejection of their IP application, they also requested compensation for unlawful detention. Meanwhile they escaped from administrative detention after being held for a couple of months shorter than two years. In one of the cases the court rejected the appeal of rejection of IP application and based on this, declined the compensation request without assessing the lawfulness of deprivation of liberty. ${ }^{48}$ In the other case the court accepted the appeal and cancelled the rejection of IP application, however again declined the compensation claim. The court's reasoning was that, in order for responsibility of the administration to arise, in addition to presence of damage, there should also be causality, meaning such damage should also be caused by an act or action attributable to administration. To the extent that the fault of a person other than the administration affects the arising of the damage, the responsibility of the administration for compensation based on service fault will be diminished. According to the court, the required degree of administration's fault is gross negligence in service. Thus, the court rejects compensation based on lack of causality between administration's act and damage as well as lack of gross negligence in service attributable to administration. ${ }^{49}$

\footnotetext{
$45 \quad$ E 2017/1376 K 2018/236 (Edirne Administrative Court).

46 E 2018/1798 K 2018/1544 (İstanbul Regional Administrative Court 10 Administrative Lawsuit Chamber).

47 E 2017/1451 K 2018/201 (Edirne Administrative Court).

48 E 2013/1311 K 2015/659 (Ankara 7 Administrative Court).

49 E 2013/1353 K 2015/2689 (Ankara 8 Administrative Court).
} 
Though limited in number, all of these decisions in administrative full remedy actions rejecting compensation for administrative detention, do not paint such an optimistic picture about the effectiveness of this legal remedy and its capacity to replace individual application to $\mathrm{CC}$. Although operation of administrative full remedy action is theoretically capable of providing effective remedy for compensation concerning administrative detention practices, its effect in practice so far, rather indicates that the condition of exhaustion of full remedy action imposed by $\mathrm{CC}$ might cast doubt as to the effectiveness of legal remedies in the eyes of the ECtHR. ECtHR in fact had to deal with a similar situation concerning Bulgaria. The Court recognized the presence of case law concerning conditions of detention in facilities for immigration detention and did not accept practical challenges caused by being foreigners as justified reasons for applicants not to exhaust domestic judicial remedies. However, since the evolution of case law of Bulgarian courts in this regard showed that individuals have no reasonable prospect of success, ECtHR started not requiring the applicants to exhaust such domestic remedies that were not operating properly. ${ }^{50}$

\section{Assessment of Claims of Compensation by CC in the Light of its Landmark Decision}

Finally, review of CC's case law after its landmark decision No. 2014/15769 reveals that the Court almost automatically declares individual applications concerning administrative detention practices inadmissible. In fact, according to the distinctions in its landmark decision, $\mathrm{CC}$ would be expected to examine the facts of the cases to see whether they contain claims that are eligible for its review. CC rightly differentiated between administrative detention practices which were found lawful and unlawful upon complaint to criminal judges of peace. Accordingly, for claims of violation of Article 19 of Constitution by administrative detention practices that were not found unlawful by criminal judges of peace, $\mathrm{CC}$ does not expect the applicants to exhaust administrative full remedy action, as explained above. This might be the case when applicants are released ${ }^{51}$ or removed from the country ${ }^{52}$ before a complaint was lodged or a decision was made by criminal judges of peace, or when their complaints were rejected.

Despite this differentiation by $\mathrm{CC}$, it is reported by the lawyers in the field that there has been many instances where CC declared individual applications inadmissible although the complaints to criminal judges of peace were also rejected. This is alarming in terms of human rights protection because there are no other remedies left in domestic

50 'ECtHR - S.F. and Others v. Bulgaria, Application No. 8138/16, 7 December 2017 | European Database of Asylum Law' $<$ https://www.asylumlawdatabase.eu/en/content/ecthr-sf-and-others-v-bulgaria-application-no-813816-7-december2017\# content> accessed 9 April 2019.

51 It was concluded in 2016/1260 Díş (İzmir 2 Criminal Judge of Peace) that there is no need to make a decision on lawfulness of administrative detention as the applicant was released due to having submitted an IP application.

52 As in the case of the applicant in 2017-34558 [2019] Constitutional Court Shakhnoza Abullaeva who was removed one week after being taken under administrative detention as reported by her lawyer. 
law concerning such practices. This was the case where appeal to administrative detention was rejected by Kayseri 3. Criminal Judge of Peace ${ }^{53}$ and individual application to CC with No. 2015/9074 was also rejected. ${ }^{54}$ Similarly, the complaint of the applicant from Uzbekistan, who submitted the individual application No. 2017/34994 to CC, was rejected by İzmir 2. Criminal Judge of Peace, ${ }^{55}$ due to presence of threat to public order, public security or public health and risk of absconding. Despite this, CC decided on 10 April 2019 that his individual application is inadmissible due to non-exhaustion of local remedies. Again, applications against administrative detention was rejected four times by criminal judges of peace based on risk of absconding and threat to public order and security in the first three, ${ }^{56}$ and, in the last complaint, based on need to extend administrative detention for non-cooperation of the applicant. ${ }^{57}$ So, CC's decision finding the claims on lawfulness of detention inadmissible due to nonexhaustion of administrative full remedy action ${ }^{58}$ constitutes inconsistency. Another example relates to a complaint rejected by Osmaniye 1. Criminal Judge of Peace on 27 December 2017. It was recognized by CC that administrative detention was finalized not because it was unlawful but in order to implement removal. Still, both claims relating to unlawfulness of administrative detention and detention conditions were found inadmissible due to non-exhaustion of administrative full remedy action. ${ }^{59}$ One final example of this type relates to and individual application which was found inadmissible due to non-exhaustion of local remedies both with respect to lawfulness and conditions of administrative detention, ${ }^{60}$ despite the applicant's complaint was repeatedly rejected by Adana, Antalya and Kirklareli Criminal Judges of Peace. ${ }^{61}$

In certain cases, although administrative detention was finally declared unlawful, multiple applications were made to criminal judges during the course of administrative detention. In such cases, although the final decision cancels administrative detention, the previous rejection decisions affirm its lawfulness. This is also compatible with facts of life as accepted by the lawmaker considering the formulation of Article 61 of the Implementing Regulation which refers to estimation that it will not be possible to conduct removal within six months of administrative detention which may arise as removal procedures progress, to emergence of serious indications as to existence

\footnotetext{
53 With its decision No. 2015/773 dated 3 April 2015.

54 With the decision combining forty-three individual applications under the application No. 2015/516.

55 With its decision No. 2017/4245 dated 17 August 2017.

56 2016/509 D $\dot{I}_{S ̧}$ (Ağrı Criminal Judge of Peace); 2016/736 D $\dot{I}_{S ̧}$ (Ağrı Criminal Judge of Peace); 2016/903 D $\dot{I}_{S ̧}$ (Ağrı Criminal Judge of Peace).

57 2016/1021 D $\dot{I}_{s ̧}$ (Ağr Criminal Judge of Peace).

58 2016-54 (Constitutional Court).

59 2018-4529 [2019] Constitutional Court Dana Ebrahimnezhad.

60 2016-59015 [2019] Constitutional Court Viktor Golovatskih.

$612016 / 3628 D$ Işs (Adana 2 Criminal Judge of Peace); 2016/2821 D $\dot{I}_{S ̧}$ (Adana 2 Criminal Judge of Peace); 2016/1363 D $\dot{I}_{S ̧}$ (Antalya 2 Criminal Judge of Peace); 2016/972 D $\dot{I}_{S ̧}$ (Antalya 2 Criminal Judge of Peace); 2016/1964 D $\dot{I}_{\text {Ş }}$ (Kırklareli Criminal Judge of Peace).
} 
of barriers to removal, to disappearance of risk of absconding, and to applicant's application for voluntary return assistance. These are identified as reasons for reviewing the necessity of administrative detention and it is possible for all of these situations to emerge at a later point in time during the course of administrative detention or administrative detention grounds that once existed to change or disappear over time. This is also confirmed with the wording of Article 57 of LFIP which makes multiple applications to criminal judges of peace possible with the claim that circumstances related to administrative detention have changed. Thus, it cannot be automatically assumed that acceptance of a complaint against administrative detention renders the whole period of administrative detention unlawful and more often than not, rejection of earlier complaints means that the judge confirms the lawfulness of administrative detention up until that point in time.

This situation was encountered by $\mathrm{CC}$ on different occasions. Complaints against administrative detention were rejected twice ${ }^{62}$ for one applicant and once for the other, ${ }^{63}$ without any reasoning as to circumstances of the case. In subsequent complaints, the relevant criminal judges of peace declared administrative detention unlawful. ${ }^{64}$ However, since these decisions cancelling administrative detention were based on expiry of six months administrative detention period and lack of any reason for extension, they actually do not contain any assessment regarding lawfulness of the administrative detention for the first six months. Thus in case of an administrative full remedy action it is not possible for the administrative court to accept the unlawfulness of the whole period of administrative detention and rule on compensation accordingly. Yet, $\mathrm{CC}$ found the individual applications inadmissible due to non-exhaustion of local remedies without making any distinction in this regard. ${ }^{65}$ Actually, it is revealed by the review of other inadmissibility decisions, following acceptance of administrative full remedy action as an effective way to demand compensation concerning administrative detention practices, that, at least eight individual applications had similar conditions. ${ }^{66}$ In all of these cases, there were multiple applications to the criminal judge of peace demanding lifting of administrative detention and some of these applications resulted with rejection until they were finally accepted with subsequent decisions or applicants were released through administrative action. However CC again fails to follow its own case law by not evaluating requests of compensation concerning the periods of administrative detention, unlawfulness of which were not declared by criminal judges of peace. In order not to prevent access to legal remedy against violations of Article 19 of Constitution, at the stage of admissibility review, CC should assess the

62 2017/2197 D $\dot{I}_{S ̧}$ (Adana 2 Criminal Judge of Peace); 2017/2261 D İş (Kırklareli Criminal Judge of Peace).

63 2017/1009 D Işs (Antalya 2 Criminal Judge of Peace).

64 2017/2853 D Işs (Kırklareli Criminal Judge of Peace); 2017/2639 D Işs (Antalya 2 Criminal Judge of Peace).

65 2017-36854 [2018] Constitutional Court Murat Tkhagapsoev; 2017/27477 (Constitutional Court).

66 2015-516 (n 4); 2014-17572 (n 4); 2014-19436 (n 4); 2014-6493 (n 4); 2015-7305 (n 4); 2014-16413 (n 4); $2015-1474$ (n 4); 2014-19481 (n 4). 
reasons of previous rejections and final acceptance by criminal judges of peace so as to differentiate the periods of administrative detention that falls within its jurisdiction concerning compensation requests.

One recent exception to this general trend of inadmissibility decisions relate to a political leader of Uyghur minority whose extradition was requested by People's Republic of China based on crimes related to terrorism. ${ }^{67}$ Whereas the case related to extradition is still pending, a removal order and an administrative detention decision was issued concerning the applicant. During the term of deprivation of liberty exceeding twelve months, his complaints were repeatedly rejected by criminal judges of peace. He claimed violation of Article 19 due to unlawfulness of detention and Article 17 of Constitution due to detention conditions for being held in isolation and having poor access to medical care. Interestingly, CC did not raise the possibility of administrative full remedy action with respect to the applicant's claims concerning detention conditions. ${ }^{68}$ The Court decided that the part of the individual application related to the claims regarding conditions of detention is inadmissible, as it found the claims of the applicant to be manifestly ill-founded. However, it reached this conclusion after a detailed assessment of claims, equivalent to what would be expected under examination of merits. The blurry line between findings of inadmissibility due to being manifestly ill-founded and findings of no violation is also acknowledged by ECtHR, as the Court describes that an application is found manifestly ill-founded if there is "no appearance of a violation or if there is settled or abundant case-law in similar or identical situations also finding no violation." ${ }^{69}$ Due to unique circumstances surrounding this individual application, considering the claims of the applicant being held in solitary confinement for an extensive period and lack of any other individual applications about the conditions in Kırklareli Pehlivanköy Removal Centre and Tekirdağ Removal Centre, it is not possible to assume that the Court considered the claims under admissibility review rather than examination of merits due to settled or abundant case-law in similar or identical situations. Similarly, considering that it is established that the applicant experienced serious medical problems and there are many documents concerning this situation that begged review by $\mathrm{CC}$, it could be argued that the Court examined the facts of the case beyond a mere determination of no appearance of violation. Special circumstances surrounding the case, such as the high profile of the case being related to a known political figure, its wide publicity in the media and significance of Turkey's political relations with People's Republic of China as well as presence of a pending application before the ECtHR by the same application with similar claims based on Article 3 of the ECHR and communicated

\footnotetext{
$67 \quad 2016-35009$ (n 4).

68 ibid 70-93.

69 Council of Europe/European Court of Human Rights, 'The Admissibility of an Application' 5.
} 
to the government, ${ }^{70}$ might have strengthened the Court's preference to examine the applicant's claims as to conditions of detention under admissibility review. Otherwise, it would not be possible for CC to do this at merits stage, because the application would have to be rejected at admissibility stage in any case, based on non-exhaustion of remedies, if not based on being manifestly ill-founded, in line with the principles set out at its decision No. 2014/15769.

$\mathrm{CC}$ took a similar position in its first decision on an individual application that includes claims concerning administrative detention conditions and decided that applicant's claims in this regard are manifestly ill-founded rather than finding no violation at merits stage. ${ }^{71}$ This is the only other case where CC examined detention conditions and did not find any violation, so, finding the claims manifestly ill-founded in this final case does not pose inconsistency in case law.

As to the claims of violation of Article 19, the Court took into account that, except the final one, all of the previous applications of the applicant to criminal judges of peace regarding the unlawfulness of detention were rejected. Also, even after administrative detention was found unlawful finally by a criminal judge of peace due to exceeding of twelve months maximum period inscribed in the legislation, the applicant claims that he continued to be held in the Removal Centre. CC states that administrative full remedy action cannot be accepted as an effective remedy under these circumstances because it does not have the possibility of enabling release of individuals from administrative detention. ${ }^{72}$ Consequently, the Court found that this part of the application is admissible and went on with the examination of the merits of the case to find violations of Article 19 for the whole duration of deprivation of liberty. Although, the line of reasoning followed in this decision is in line with the principles outlined in CC's decision No. 2014/15769, the sample cases noted above reveals that this decision does not represent CC's general practice.

\section{Conclusion}

Right to personal liberty and security is of paramount importance in Turkish and ECHR framework alike. Therefore the fulfillment of right to compensation related to administrative detention of foreigners is a crucial matter of rights protection. Thus, this paper aspired to make an original contribution to literature by analyzing Turkish case law on compensation for unlawful practices of administrative detention. In this regard the dynamic case law of $\mathrm{CC}$ guides the field as well as the case law of local courts.

\footnotetext{
70 Communicated Case Yapuquan v Turkey (ECtHR).

$71 \quad 2013-9673$ (n 3)

$72 \quad 2016-35009$ (n 4) paras 99-101.
} 
In the first phase of CC decisions, the framework was criticized due to lack of clear regulation as to conditions and legal remedies with respect to administrative detention. Absence of a mechanism for compensation of unlawful practices of administrative detention yielded CC to accept the applicants' complaints and grant them compensation. This was followed by the landmark decision No. 15769 where CC changed its position radically. It ruled that administrative full remedy action before administrative courts must be exhausted in the cases where the unlawfulness of administrative detention is already established by criminal judges of peace and where the complaint is based on conditions rather than lawfulness of administrative detention. Consequently, contrary to its previous practice, $\mathrm{CC}$ expresses that individual application may not be lodged before exhausting administrative full remedy action. This paper argued that this evolution of case law is problematic for several reasons. Firstly, the examples of administrative full remedy action reveal a very pessimistic picture as to its effectiveness. Secondly, even in the absence of a criminal judge of peace decision declaring administrative detention measure unlawful, the $\mathrm{CC}$ rejects reviewing the merits of individual applications and finds them inadmissible, in contradiction with its landmark decision.

Consequently the current judicial practice of Turkish courts cast a shadow on the effectiveness of legal remedies for compensation of damages related to unlawful practices of administrative detention. The position of ECtHR remains to be seen in terms of assessment with respect to ECHR framework on right to personal liberty and security as well as right to effective remedy.

\footnotetext{
Peer-review: Externally peer-reviewed.

Conflict of Interest: The author has no conflict of interest to declare.

Grant Support: The author declared that this study has received no financial support.

Hakem Değerlendirmesi: Dış bağımsız.

Çıkar Çatışması: Yazar çıkar çatışması bildirmemiştir.

Finansal Destek: Yazar bu çalışma için finansal destek almadığını beyan etmiştir.
}

\section{Bibliography/Bibliyografyay}

Çağlayan R, İdare Hukuku Dersleri (6th edn, Adalet Yayınevi 2018)

Council of Europe/European Court of Human Rights, 'The Admissibility of an Application'

'ECtHR - S.F. and Others v. Bulgaria, Application No. 8138/16, 7 December 2017 | European Database of Asylum Law' <https://www.asylumlawdatabase.eu/en/content/ecthr-sf-and-othersv-bulgaria-application-no-813816-7-december-2017\#content $>$ accessed 9 April 2019

Kalabalık H, Idare Hukuku Dersleri Cilt-II (4th edn, Seçkin Yayınc1lık 2019)

Mole N and Meredith C, Asylum and the European Convention on Human Rights (Council of Europe Publishing 2010)

Abdolkhani and Karimnia v Turkey [2009] ECtHR 30471/08

Alimov v Turkey [2016] ECtHR 14344/13 
Amerkhanov v Turkey [2018] ECtHR 16026/12

Amie and Others v Bulgaria [2015] ECtHR 58149/08

Athary v Turkey [2012] ECtHR 50372/09

Batyrkhairov v Turkey [2018] ECtHR 69929/12

Boudraa v Turkey [2017] ECtHR 1009/16

Chahal v the United Kingdom [1996] ECtHR 22414/93

Communicated Case Yapuquan v Turkey (ECtHR)

Dbouba v Turkey [2010] ECtHR 15916/09

E 2013/1311 K 2015/659 (Ankara 7 Administrative Court)

E 2013/1353 K 2015/2689 (Ankara 8 Administrative Court)

E 2017/1322 K 2018/338 (İstanbul 1 Administrative Court)

E 2017/1376 K 2018/236 (Edirne Administrative Court)

E 2017/1451 K 2018/201 (Edirne Administrative Court)

E 2018/499 K 2018/562 (Edirne Administrative Court)

E 2018/1254 K 2018/2324 (İstanbul 1 Administrative Court)

E 2018/1798 K 2018/1544 (İstanbul Regional Administrative Court 10 Administrative Lawsuit Chamber)

E 2018/2202 K 2018/2042 (İstanbul Regional Administrative Court 10 Administrative Lawsuit Chamber)

E1937/202 K1938/14 (Council of State 2 General Council of Lawsuit Chambers)

E1965/21 K1966/7 (Council of State Board for Unification of Case Law)

E1975/542 K1975/519 (Council of State 3 Chamber)

E1980/32 K1980/39 (Council of State 3 Chamber)

E1991/112 K1991/154 (Council of State 5 Chamber)

E1993/247 K1994/559 (Council of State 3 General Chamber of Administrative Lawsuits)

E2003/14 K2003/25 (Council of State 1 Chamber)

$G$ B and Others $v$ Turkey [2019] ECtHR 4633/15

Moghaddas v Turkey [2011] ECtHR 46134/08

Musaev v Turkey [2014] ECtHR 72754/11

Tehrani and Others $v$ Turkey [2010] ECtHR 32940/08, 41626/08 and 43616/08

Yarashonen v Turkey [2014] ECtHR 72710/11

2013-655 [2016] Constitutional Court F.A. and M.A.

2013-1649 [2016] Constitutional Court A.V. and Others

2013-8735 [2016] Constitutional Court F.K. and Others

2013-8810 [2016] Constitutional Court T.T.

2013-9673 [2015] Constitutional Court Rida Boudraa

2014-688 [2017] Constitutional Court İ.U.

2014-1368 [2017] Constitutional Court A.S. 
2014-1369 [2017] Constitutional Court A.B.

2014-2114 [2017] Constitutional Court U.U.

2014-2427 [2018] Constitutional Court D.D.

2014-2841 [2016] Constitutional Court A.S.

2014-3955 [2018] Constitutional Court R.A.

2014-6493 [2018] Constitutional Court M.B. and M.Z.

2014-13044 [2015] Constitutional Court K.A.

2014-15769 [2017] Constitutional Court B.T.

2014-15824 [2016] Constitutional Court I.S. and Others

2014-15876 [2016] Constitutional Court I.I.

2014-16413 [2017] Constitutional Court I.M. and Z.M.

2014-16575 [2018] Constitutional Court K.K.

2014-16577 [2018] Constitutional Court K.A. and N.A.

2014-17572 [2019] Constitutional Court A.A. and Others

2014-18827 [2017] Constitutional Court A.A.

2014-19436 [2018] Constitutional Court M.A.

2014-19481 [2018] Constitutional Court G.B. and Others

2014-19690 [2018] Constitutional Court M.S.S.

2015-33 [2019] Constitutional Court Sara Rahmazani and Others

2015-516 [2019] Constitutional Court Dayginat Magomedzhamilova and Others

2015-1474 [2018] Constitutional Court Manzura Jumaeva

2015-4459 [2018] Constitutional Court Yulia Matur (Anikeeva)

2015-5371 [2017] Constitutional Court Gulalek Begnyazova

2015-6543 [2018] Constitutional Court G.G.

2015-6724 [1.8.20220] Constitutional Court Solmaz Mamedova

2015-7305 [2018] Constitutional Court M.A.

2015-8465 [2018] Constitutional Court K.M.

2015-9409 [2019] Constitutional Court Abdullah Omar

2015-9727 [2019] Constitutional Court Feruza Masulmankulova

2015-9776 [2018] Constitutional Court F.M.

2015-9777 [2019] Constitutional Court A.O.C and Others

2015-10697 [2019] Constitutional Court Mohammaod Alhowees

2015-10715 [2019] Constitutional Court Nader Alomar

2015-10717 [2019] Constitutional Court Fadi Mansour

2015-11553 [2019] Constitutional Court M. Q.

2015-15764 [2018] Constitutional Court F.A.A.

2015-17761 [2019] Constitutional Court A.A.K.

2015-18312 [2019] Constitutional Court A.E.H. ve S.E.I. 
2015-19133 [2019] Constitutional Court R.M. and Others

2016-54 (Constitutional Court)

2016/509 D $\dot{I}_{\text {ş (Ağrı Criminal Judge of Peace) }}$

2016/736 D $\dot{I}_{\text {ş }}$ (Ağrı Criminal Judge of Peace)

2016/903 D $\dot{I}_{\text {ş }}$ (Ağrı Criminal Judge of Peace)

2016/972 D $\dot{I}_{S}$ (Antalya 2 Criminal Judge of Peace)

2016/1021 D Işs (Ağrı Criminal Judge of Peace)

2016/1260 Dişs (İzmir 2 Criminal Judge of Peace)

2016/1363 D Işs (Antalya 2 Criminal Judge of Peace)

2016-1508 [2020] Constitutional Court Mohamed Khaled Alswadane

2016/1964 D İş (Kırklareli Criminal Judge of Peace)

2016/2821 D $\dot{I}_{s ̧}$ (Adana 2 Criminal Judge of Peace)

2016/3628 D $\dot{I}_{s ̧}$ (Adana 2 Criminal Judge of Peace)

2016-4754 [2020] Constitutional Court Kristina Lutstsato and Others

2016-5688 [2017] Constitutional Court A. S.

2016-12585 [2020] Constitutional Court Sonia Nasir

2016-12809 [2020] Constitutional Court Kemal Salpagarov

2016-23744 [2020] Constitutional Court Nuli Aihetamu

2016-26503 [2017] Constitutional Court Fatma Bakki

2016-27304 [2017] Constitutional Court H. B.

2016-35009 [2019] Constitutional Court Abdulkadir Yapuquan

2016-40091 [2020] Constitutional Court Mohamed Sabry Aly Azzazy and Others

2016-59015 [2019] Constitutional Court Viktor Golovatskih

2016-70639 [2019] Constitutional Court Magomed Emin Osmaev

2017/1009 D Işs (Antalya 2 Criminal Judge of Peace)

2017/2197 D $\dot{I}_{s ̧}$ (Adana 2 Criminal Judge of Peace)

2017/2261 D Işs (Kırklareli Criminal Judge of Peace)

2017/2639 D İş (Antalya 2 Criminal Judge of Peace)

2017/2853 D İş̧ (Kırklareli Criminal Judge of Peace)

2017-5839 [2017] Constitutional Court M. I.

2017-6077 [2017] Constitutional Court F.R.

2017-10453 [2017] Constitutional Court Y. H.

2017-19685 [2017] Constitutional Court Zamow Muhammed

2017-20451 [2020] Constitutional Court Ali Javid and Others

2017-23177 [2018] Constitutional Court P.A.

2017-24530 [2020] Constitutional Court Mostafa Soleymani Olyae and Others

2017/27477 (Constitutional Court)

2017-31040 [2019] Constitutional Court Z.K. 
2017-34558 [2019] Constitutional Court Shakhnoza Abullaeva

2017-36854 [2018] Constitutional Court Murat Tkhagapsoev

2017-38222 [2018] Constitutional Court F.Y.

2018-4529 [2019] Constitutional Court Dana Ebrahimnezhad

2019-7023 [2019] Constitutional Court A.H.

2019-9386 [2019] Constitutional Court Nashaat Alalloush

2019-14737 [2019] Constitutional Court T. S.

2019-18314 [2019] Constitutional Court Basel Khalil

2019-19576 [2020] Constitutional Court Behzad Zareei 